The material of this paper has been extracted from a thesis for the degree of M.D. Cambridge, I95I, and the author is grateful to the Regius Professor of Medicine for permission to publish it. The work of nutrition surveys in Berlin during the blockade was carried out with Drs H. E. Magee and P. J. Cowin of the Ministry of Health, whose help the author gratefully acknowledges.

\title{
REFERENCES
}

Berry, W. T. C., Cowin, P. J. \& Magee, H. E. (195I). Mon. Bull. Minist. Hlth Lab. Serv, 10, 155. de Jongh, C. L. (1948). In Malnutrition and Starvation in Western Netherlands, Part I, p. 97. [G. C. E. Burger, H. R. Sandstead and J. C. Drummond, editors.] The Hague: General State Printing Office.

Smart, G. A., Macrae, T. F., Bastenie, P. A. \& Gregoire, P. E. (1948). Brit. med. F. i, 40.

Taylor, G. F. \& Chhuttani, P. N. (1949). Brit. med. F. ii, 784 .

\section{The Absence of Anti-thyroid Properties for Rats in Two Types of Groundnut Oil in Common Use in Nigeria}

\author{
By JOYCE BUXTON, HILARY M. GRUNDY AND DAGMAR C. WILSON \\ Laboratory of Human Nutrition, University of Oxford \\ AND D. G. JAMISON \\ Laboratory of Physiology, University of Oxford
}

(Received 26 November I953)

Nigeria has the largest area of groundnut cultivation in the world and groundnut oil is commonly used as a food in the Northern Territory. There is a traditional method for the extraction of the oil by hand: the groundnuts are shelled, roasted and pounded to a paste; this paste is then kneaded with hot water and thoroughly mixed; the resulting sludge is put into a large pot, placed on a slow fire and kept constantly mixed. The floating oil is collected as it comes up to the surface. This operation is continued until no further oil is obtained and the residue in the pan becomes charred, giving the oil a strong flavour.

\section{EXPERIMENTAL}

Two samples of groundnut oil, one an indigenous hand-made oil and the other an unrefined crude oil, extracted by machine at Kano, Northern Nigeria, were sent to Oxford for testing their possible anti-thyroid properties in rats. Twenty-four male hooded rats, $7-8$ weeks old and weighing roo-1 $3^{2} \mathrm{~g}$, were fed on the following basic diet:

$\begin{array}{lrlr}\text { Sucrose } & 65 \% & \text { Groundnut oil } & 10 \% \\ \text { Casein (fat- and vitamin-free) } & 20 \% & \text { Salts } & 5 \%\end{array}$


The salt mixture of Hegsted, Mills, Elvehjem \& Hart (I94I) was modified to provide an adequate but not excessive amount of iodine $(2 \cdot 8 \mu \mathrm{g} / \mathrm{rat}$ daily). The following water-soluble vitamins were given daily by mouth separately from the food:

$\begin{array}{lllr}\text { Thiamine hydrochloride } & 0.1 \mathrm{mg} & \text { Inositol } & 2.0 \mathrm{mg} \\ \text { Riboflavin } & 0.16 \mathrm{mg} & \text { Choline chloride } & 10.0 \mathrm{mg} \\ \text { Nicotinic acid } & 1.0 \mathrm{mg} & p \text {-Aminobenzoic acid } & \mathrm{I} .0 \mathrm{mg} \\ \text { Pyridoxin hydrochloride } & 0.1 \mathrm{mg} & \text { Pteroylglutamic acid } & 0.02 \mathrm{mg} \\ \text { Calcium pantothenate } & 0.2 \mathrm{mg} & \text { Vitamin } \mathrm{B}_{12} & 0.05 \mu \mathrm{g} \\ \text { Biotin } & 0.002 \mathrm{mg} & \text { Vitamin K ('Synkavit') }^{0.1 \mathrm{mg}}\end{array}$

All animals received rooo i.u. vitamin $A$, Ioo i.u. vitamin $\mathrm{D}$ and $5 \mathrm{mg} \alpha$-tocopherol acetate weekly by mouth.

The rats were divided into three groups, each group composed of eight animals. The groundnut oil given to the control group was oleum arachis (B.P.), in the second group the indigenous hand-made oil and in the third group the unrefined machineextracted crude oil were given.

Male animals were selected, as the oestrus may affect the female thyroid.

This long-term experiment was carried out for a period of 20 weeks. The animals were then killed under ether and the thyroid glands were dissected out and weighed. One lobe of the thyroid was taken up in sodium hydroxide, and the total iodine assayed using modifications of the methods of Talbot, Butler, Saltzman $\&$ Rodriguez (1944) for digestion and distillation, combined with the colorimetric estimations described by Taurog \& Chaikoff (1946). The other lobe of the thyroid gland was taken

Table $\mathrm{r}$. Weight and total iodine content of thyroid glands of rats given different types of groundnut oil

\begin{tabular}{lccc} 
& \multicolumn{3}{c}{ (Mean values with standard deviations for groups of eight male rats) } \\
& Oleum arachis & Indigenous & Unrefined crude \\
& (B.P.) & hand-made oil & machine-made oil \\
Weight (mg/roo g body-weight) & $7 \cdot 0 \pm \mathrm{I} \cdot 2$ & $6.8 \pm 0.6$ & $6 \cdot 9 \pm \mathrm{I} \cdot \mathrm{I}$ \\
Total iodine content & $98 \pm 12$ & $108 \pm 19$ & $107 \pm \mathrm{I} 7$ \\
(mg/100 g thyroid gland) & & &
\end{tabular}

for histological investigation at the time of death and fixed in $5 \%$ formol-saline. Tissues were fixed for $24 \mathrm{~h}$, embedded in paraffin and cut at $6 \mu$. Sections were stained with haematoxylin and eosin and examined.

\section{RESULTS}

The results in Table $\mathrm{r}$ show that there were no differences between the three groups in weight of thyroid glands (as expressed per roo $\mathrm{g}$ body-weight) or in the total iodine in the thyroid gland.

On histological examination, although the glands were not exactly similar, in no instance did they show clear evidence of hyperplasia; isolated vesicles in one gland of a group of eight might show suggestive changes but these were never reproduced in the other members of the same series. An initial examination revealed slight morphological alteration from one gland to the next; further attempts to classify on 
these slight changes or to find definite evidence of hyperplasia invariably resulted in failure. There was no histological evidence that the oils fed to the rats had any goitrogenic properties.

\section{DISCUSSION}

Mellanby (1934) fed bitches, kept during pregnancy in kennels, with natural foods of a low-iodine content and found that groundnut oil produced hyperplasia in the thyroid gland of a puppy. Greer \& Astwood (1948) studied the effect of radioactive iodine in man and found that the anti-thyroid activity of peanuts was unaffected by heat; they found the anti-thyroid effect of heated peanuts ' $I$ ', as compared with the highest effect, ' $3-4$ ', of rutabaga (yellow turnip or swede (Brassica campestris)). Later, Astwood (1949) considered it was not certain which foods are certainly goitrogenic but that the possibility of an anti-thyroid compound in peanuts deserved exploration, and Greer (1950) stated that the goitrogenic effects of peanuts in man might be questionable.

This experiment provides no evidence that the groundnut oil used by the indigenous population in Northern Nigeria held any anti-thyroid properties for rats fed on a purified diet.

\section{SUMMARY}

I. An experiment using rats was undertaken to investigate the possible antithyroid effects of two types of groundnut oil in common use in Northern Nigeria.

2. On the basis of weights of thyroid glands, estimations of total iodine and histological examination of the thyroid glands, it is concluded that the groundnut oil had no goitrogenic properties for rats.

We are grateful to Dr H. M. Sinclair for advice and for dissections of the thyroid glands.

\section{REFERENCES}

Astwood, E. B. (1949). Ann. intern. Med. 30, 1087.

Greer, M. A. (1950). Physiol. Rev. 30, 5 I3.

Greer, M. A. \& Astwood, E. B. (1948). Endocrinology, 43, 105.

Hegsted, D. M., Mills, R. C., Elvehjem, C. A. \& Hart, E. B. (I94I). F. biol. Chem. 138, 459.

Mellanby, E. (1934). Nutrition and Disease. Edinburgh: Oliver and Boyd.

Talbot, N. B., Butler, A. M., Saltzman, A. H. \& Rodriguez, P. M. (1944). F. biol. Chem. r53, 479.

Taurog, A. \& Chaikoff, I. L. (1946). F. biol. Chem. 163, $3^{1} 3$. 